\title{
Magmatic Gases Extracted and Analysed from Ocean Floor Volcanics
}

M. CHAIGNEAU

R. HËKINIAN

J.L. CHEMINÉE
Laboratoire des Gaz, Université $R$. Descartes, 4, avenue de l'Observatoire, 75006 Paris.

Centre Océanologique de Bretagne, B.P. 337, 29273 Brest Cedex.

Laboratoire de Géologie, Ecole Nationale Supérieure, 46, rue d'Ulm, 75005 Paris.

\section{ABSTRACT}

- Magmatic gases extracted and analysed from basaltic rocks collected in the FAMOUS area near $36^{\circ} 50^{\prime} \mathrm{N}$ in the Atlantic ocean show that the total amount of gas included in the samples varies between about $500 \mathrm{ppm}$ to $1600 \mathrm{ppm}$. The main gaseous phases included in the various types of basalts consist of $\mathrm{CO}_{2}$ (270$700 \mathrm{pprn}), \quad \mathrm{CO} \quad(150-800 \mathrm{ppm}), \mathrm{HCl}(100-$ $1000 \mathrm{ppm}), \quad \mathrm{H}_{2} \quad(0-50 \mathrm{ppm}), \mathrm{SO}_{2}$ (up to $175 \mathrm{ppm}$ ), $\mathrm{N}_{2}$ (up to about $213 \mathrm{ppm}$ ) and traces of hydrocarbons (up to about $24 \mathrm{ppm}$ ). The relative amount of $\mathrm{CO}, \mathrm{CO}_{2}$ and $\mathrm{SO}_{2}$ varies with both the degree of crystallinity of the rock and with fractional crystallization and/or fractional melting. The glassy margin of pillow lavas have a higher $\mathrm{CO} / \mathrm{CO}_{2}$ ratio than the more crystalline interior. The most fractionated rocks of the series rich in clinopyroxene are depleted in the $\mathrm{CO} / \mathrm{CO}_{2}$ ratio and have a higher $\mathrm{SO}_{2}$ content than do the most mafic end members rich in olivine. Early-formed olivine was crystallized in a reducing environment rich in $\mathrm{CO}$ and $\mathrm{H}_{2}$ with respect to later formed mineral associations. It is likely that the carbon and sulfur oxidation is taking place at a relatively shallow depth during magmatic ascent or during volcanism. The ocean floor volcanics when compared to subaerial basalts are depleted in $\mathrm{SO}_{2}$ and have on the average ten times more $\mathrm{H}_{2 \cdot}$

\section{INTRODUCTION}

Volcanic activities in both subaerial and subaqueous environments are accompanied by magmatic emanations: such magmatic emanations consist of a fluid which is differentiated into a liquid and a gaseous phase.

The study of volcanic gases began during the last century primarily with the work of FOUQUET (1879) and others. However it was in the first quarter of this century that volcanic gases were intensively collected from subaerial volcanoes and studied (CHAMBERLIN, 1908; BRUN, 1911; SHEPERD, 1938; JAGGAR, 1940; NEMOTO et al., 1957; WHITE and WARING, 1963; HEALD et al., 1963; ElSKENS et al., 1969). Gas analyses of recently active volcanoes of the workd such as the Hawaiian volcanoes of Kilaula (MATSUYO, 1960; HEALD et al., 1963), Mount Mihara in Japan (IWASAKI et al., 1968) and Mount Etna in Italy (CHAIGNEAU and BORDET, 1962; Huntington, 1963; SATO and MOORE, 1973) were studied in detail. However, the role of the volatile phase in volcanic processes in still poorly known. Measuring the gas content emitted by subaerial volcanoes is a difficult task, since it is likely that contamination by air might take place during the process of gas collecting. For istance it was suggested (HUNTINGDON, 1973) that in order to minimize contamination by air, the gas temperature at the time of collection should be close to that of the lava (about 1050$1100^{\circ} \mathrm{C}$ ). Obviously such a high temperature raises some difficulty in direct sampling.

Another approach to the study of magmatic gas is the recognition of mineral

Bull. Volcanol., Vol. 43-1, 1980. 
phases or mineral compounds containing volatiles in their structural networks. Recently analyses of sulfide globules containing sulfur, nickel, copper and iron were studied from ocean floor volcanics (MoORE and CALK, 1977; MOORE and SCHILLING, 1972; CZAMANCKE and MOORE, 1977). MOORE et al. (1977) have shown that volatile-filled vesicles are present in minor amounts in all mid-ocean ridge basalts. They have found that $\mathrm{CO}_{2}$ is the main gas component occurring in the vesicles of ocean floor basalts. As fluid inclusions were found to occur in minerals of various granitic and/or pegmatitic formation in continental area (INGERSON, 1974; WEISBROD et al., 1976) and in olivine-bearing nodules (ROEDDER, 1965). Fluids inclusions have been analysed from various mineral phases found in ocean floor rocks (JEHL, 1975). It was suggested that main fluidal phases included in quartz, calcite and feldspar of oceanic rocks are of an aqueous nature (JEHL, 1975). Other recent studies on the gas content of rocks from the ocean floor were primarily concentrated on the samples collected in the FAMOIIS area (HÉKINIAN et al., 1975; PINEAU et al., 1976).

Knowledge about the fluid content of the oceanic crust is important in experimental petrology in order to speculate on the influence of a partial pressure of the volatiles during mineral paragenesis in relation to the basaltic melt. It is also of primary interest to have an idea about the content of fluid phases present in preeruptive melts in order to speculate on processes related to the hydrothermal circulation of the oceanic crust. Since volcanic activities on the ocean floor are one of the major processes involved in creating near crustal material, it is important to evaluate the budget of volatile discharge into sea water and its subsequent contribution to the formation of the hydrosphere.

The samples studied here are those collected from the FAMOUS area located near $36^{\circ} 50^{\prime} \mathrm{N}$ in the rift valley of the Mid-Atlantic Ridge. They were described in detail elsewhere (HÉKINIAN et al., 1976; ARCYANA, 1977) and consist of picritic basalt, olivine basalt, plagioclase-rich basalt and plagioclase-pyroxene basalt with or without olivine. The study of gaseous phases in oceanic rocks from the FAMOUS area was done systematically on petrographically well classified specimens. Chemical and modal analyses of the rocks studied here are shown in Tables 1 and 2. The purpose of this study is to determine the amount of gas content during recent ocean floor volcanism and to correlate the

'TABLE 1 - Modal analyses of basaltic rocks from the mid-Atlantic ridge Rift Valley near $36^{\circ} \mathrm{N}$. The modal count was made on the most crystalline part of the rock analysed for their gas content The mesostasis consists mainly of glass and dark amorphous material. The modal analyses of samples 7-5, 7-8, 8-10 and 10-16 are from ARcYANA (1977). (n.d.) indicates not determined. The amount of the vesicles which were not determined do not exceed generally $3 \%$ of the bulk rock composition.

\begin{tabular}{|c|c|c|c|c|c|c|c|c|c|c|c|c|c|}
\hline MONAL VOL. I & $\begin{array}{l}\text { ARP } 73 \\
10-2\end{array}$ & $\underset{9-13}{\operatorname{ARP} \% 1}$ & $\begin{array}{c}\text { ARP } 73 \\
13-4\end{array}$ & $\begin{array}{c}\text { ARP } 74 \\
10-3\end{array}$ & $\begin{array}{c}\text { ARP } 74 \\
7-5\end{array}$ & $\begin{array}{c}\text { ARP } 74 \\
7-8\end{array}$ & $\begin{array}{c}\text { ARP } 74 \\
8-10\end{array}$ & $\begin{array}{r}\text { ARP } 74 \\
10-16\end{array}$ & $\begin{array}{l}\text { DR } 4 \\
329\end{array}$ & $\begin{array}{l}\text { DR } 1 \\
112\end{array}$ & $\begin{array}{l}\mathrm{CH} 31 \\
\mathrm{DR} 2 \\
132\end{array}$ & $\begin{array}{ll}\text { CH } & 31 \\
\text { DR } & 11 \\
315 X\end{array}$ & $\begin{array}{ll}\text { CH } & 31 \\
\text { DR } 11 \\
315 Y\end{array}$ \\
\hline Plagioclase & 39 & 40.90 & 39.4 & 17.74 & 21.75 & 33.32 & 22.48 & 19.82 & 11.4 & 25.5 & 36.7 & - & - \\
\hline Pyroxene & 32 & 0.3 & - & 0.3 & 9.25 & 33.2 & - & 28.99 & - & 5.8 & 7.7 & - & - \\
\hline Olivine & 3 & 2.4 & 32.9 & 39.1 & 16.5 & 11.67 & 12.39 & 47.79 & 3.6 & 6.8 & 1.4 & $<1$ & 2.3 \\
\hline Opaques & - & - & - & 1.2 & 2.5 & 6.50 & - & 1.0 & - & - & 10.7 & - & - \\
\hline Vesicles & 4 & 1.05 & n.d. & n.d. & n.d. & n.d. & n.d. & n.d. & n.d. & n.d. & n.d. & $<3$ & 5.7 \\
\hline Mesostasis & 25 & 55.34 & 27.6 & 41.0 & 50.25 & 17.30 & 65.13 & 4.87 & 84.9 & 62.7 & 43.48 & 96 & 9.2 \\
\hline
\end{tabular}


various gaseous phases with the bulk rock composition. A comparison between subaqueous and sub-aerial volcanism is made in order to have an insight on the magmatic evolution related to different types of volcanism.

\section{ANALYTICAL PROCEDURES}

The extraction of gas from the analysed rocks made in two stages: 1 ) The material was first ground to a size of about 3-6 $\mathrm{mm}$ in diameter; 2) The second stage of grinding consists of breaking up the material into a fine powder ( $0.125 \mathrm{~mm}$ mesh). After each stage of grinding the gas was extracted by heating the material up to $1000^{\circ} \mathrm{C}$ in a vacuum. About 10 grams of samples are put into a platinum capsule which in turn is introduced into a silicon tube connected to a mercury tube of the Sprendel type (ChaIGNeAU, 1975) (Fig. 1). At one end of this tube there are two recipients, one containing $\mathrm{P}_{2} \mathrm{O}_{5}$ which retains the water and a second recipient with $\mathrm{Ag}_{3} \mathrm{PO}_{4}$ used to fix $\mathrm{HCl}$ and other halogens. The volume of the gas extracted is measured and exprimed at $\mathrm{O}^{\circ} \mathrm{C}$ and $760 \mathrm{~mm}$ of $\mathrm{Hg}$. The analyses of the different gaseous phases extracted are done using a mass spectrometer (Varian-Mat of the type CH-4). In order to measure the content of the gaseous components having the same atomic number (e.g. $\mathrm{CO}$ and $\mathrm{N}_{2}$ ) it is necessary to perform two separate analyses. The content of $\mathrm{HCl}$ is calculated from the amount of silver chloride formed when hydrogen chloride reacts with silver phosphate. The precision of the method as far as the major gaseous phases are concerned is about one percent (e.g. 30.0 per 100 corresponds to $30.0 \pm 0.3$; Chaigneal, 1975).

\section{MAGMATIC GASES}

The magmatic gases studied here are believed to be concentrated mainly as fluid and/or gaseous inclusions in mineral phases such as olivine, plagioclase and clinopyroxene or as residual volatile compounds in the matrix (mesostasis and/or glass). The concentration of volatiles in phenocrystic or microphenocrystic material suggested a relatively deep-seated origin directly related to the magmatic fluid trapped into a solid phase during the early stage of crystallization. Thus the separated minerals analysed for their gaseous

TABLE 2 - Chemical analyses of basaltic rocks from the mid-Atlantic Ridge Rift Valley near $36^{\circ} 50^{\prime} \mathrm{N}$. The analyses of the pillow lava margins were made on the glassy chilled surface. Int. indicates the bulk analyses of the pillow lava interior. The matrix consists of cryptocrystalline material mechanically separated from the bulk rock.

\begin{tabular}{|c|c|c|c|c|c|c|c|c|c|c|c|c|c|c|c|}
\hline $\begin{array}{l}\text { Oxides } \\
\text { wt \& }\end{array}$ & \begin{tabular}{|l|} 
CH 31 \\
DR 4 \\
329 \\
MARGIN
\end{tabular} & $\begin{array}{l}\mathrm{CH} \\
\mathrm{DR} \\
322 \\
322 \\
\text { MARGIN }\end{array}$ & $\begin{array}{l}\mathrm{CH} 31 \\
\text { DR } 9 \\
322 \\
\text { INT. } \\
\text { WHLLE } \\
\text { ROCK }\end{array}$ & \begin{tabular}{|l|} 
CH 31 \\
DR 8 \\
326 \\
MATRIX
\end{tabular} & {$\left[\begin{array}{l}\mathrm{CH} 31 \\
\mathrm{DR} \\
326 \\
\text { INT. } \\
\text { WHOLE } \\
\text { ROCK }\end{array}\right.$} & $\begin{array}{l}\text { CH 31 } \\
\text { DR12 } \\
316 \\
\text { MATRIX }\end{array}$ & $\begin{array}{l}\text { CH } 31 \\
\text { DR } 12 \\
316 \\
\text { LNT. } \\
\text { WHDLE } \\
\text { ROCK }\end{array}$ & $\begin{array}{l}\text { CH } 31 \\
\text { DR } 11 \\
213 Y \\
\text { MARGIN }\end{array}$ & 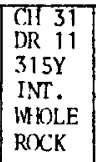 & \begin{tabular}{|l|} 
CF 31 \\
ARP74 \\
$7-5$ \\
MARGIN
\end{tabular} & $\begin{array}{l}\text { CH 31 } \\
\text { ARP74 } \\
7-5 \\
\text { INT. } \\
\text { WHOLE } \\
\text { ROCK }\end{array}$ & $\begin{array}{ll}\mathrm{CH} & 31 \\
\mathrm{DR} & 1 \\
112 \\
\text { INT. } \\
\text { WHOLE } \\
\text { ROCK }\end{array}$ & $\begin{array}{ll}\mathrm{CH} & 31 \\
\mathrm{DR} & 2 \\
132\end{array}$ & $\begin{array}{l}\mathrm{CH} 31 \\
\mathrm{DR} 11 \\
315 \mathrm{X}\end{array}$ & \\
\hline $\mathrm{SiO}_{2}$ & 50.23 & 49.94 & 49.92 & 48.40 & 47.70 & 48.23 & 47.05 & 50.04 & 48.74 & 50.96 & 50.00 & 49.86 & 49.65 & 49.68 & \\
\hline $\mathrm{Al}_{2} \mathrm{O}_{3}$ & 14.87 & 15.04 & 15.29 & 15.40 & 13,97 & 15.12 & 13.49 & 14.90 & 14.57 & 14.99 & 14.72 & 15.03 & 19.25 & 14.70 & \\
\hline $\mathrm{Fe}_{2} \mathrm{O}_{3}$ & - & 1.34 & 1.66 & - & 0.89 & - & 1.04 & - & 1.86 & - & 1.43 & 1.87 & 1.24 & 1.52 & \\
\hline $\mathrm{FeO}$ & 9.55 & 8.24 & 8.03 & 8.28 & 7.67 & 8.46 & 7.72 & 10.21 & 10.55 & 9.24 & 8.88 & 6.81 & 5.51 & 10.30 & \\
\hline $\mathrm{MnO}$ & - & 0.18 & 0.18 & - & - & 0.15 & 0.17 & - & - & - & 0.14 & 0.15 & 0.10 & - & \\
\hline Mgo & 8.64 & 9.02 & 9.12 & 10.50 & 16.08 & 12.86 & 16.65 & 8.21 & 8.16 & 8.28 & 8.00 & 10.65 & 6.90 & 8.15 & \\
\hline $\mathrm{CaO}$ & 11.96 & 12.59 & 12.55 & 12.77 & 11.50 & 12.66 & 11.42 & 11.61 & 11.70 & 12.67 & 11.65 & 12.04 & 14.60 & 11.77 & . \\
\hline $\mathrm{Na}_{2} \mathrm{O}$ & 2.10 & 2.08 & 2.23 & - & 1.57 & - & 0.37 & - & 2.15 & - & 2.36 & 2.20 & 1.80 & 2.29 & \\
\hline $\mathrm{K}_{2} \mathrm{O}$ & 0.17 & 0.13 & 0.13 & 0.14 & 0.10 & 0.10 & 0.08 & 0.22 & 0.23 & 0.16 & 0.28 & 0.16 & 0.12 & 0.22 & \\
\hline $\mathrm{TiO}_{2}$ & 1.12 & 1.04 & 1.04 & 0.68 & 0.60 & 0.64 & 0.59 & 1.43 & 1.43 & 1.09 & 1.43 & 0.90 & 0.15 & 1.44 & \\
\hline $\mathrm{P}_{2} \mathrm{O}_{5}$ & 0.12 & 0.10 & 0.10 & - & 0.03 & 0.07 & 0.18 & - & 0.18 & - & 0.16 & 0.09 & 0.11 & 0.18 & \\
\hline $\mathrm{H}_{2} \mathrm{O}^{11} 0^{\circ} \mathrm{C}$ & 0.09 & 0.09 & 0.12 & - & 0.06 & 0.05 & 0.07 & - & 0.05 & $=$ & 0.21 & 0.07 & 0.09 & 0.07 & \\
\hline $\mathrm{H}_{2} \mathrm{O}^{1050^{\circ} \mathrm{C}}$ & 0.56 & 0.55 & 0.56 & - & 0.27 & 0.53 & 0.45 & - & 0.47 & - & 0.79 & 0.40 & 0.56 & 0.58 & \\
\hline TOTAL & 99.34 & 100.31 & 100.87 & - & 100.49 & 98.76 & 100.59 & - & 100.08 & - & 100.04 & 100.08 & 100.63 & 100.89 & \\
\hline $\mathrm{FeO} / \mathrm{MgO}$ & 1.10 & 1.04 & & 0.79 & 0.53 & 0.66 & & 1.24 & 1.27 & 1.12 & 1.27 & 0.80 & 0.96 & 1.43 & \\
\hline
\end{tabular}




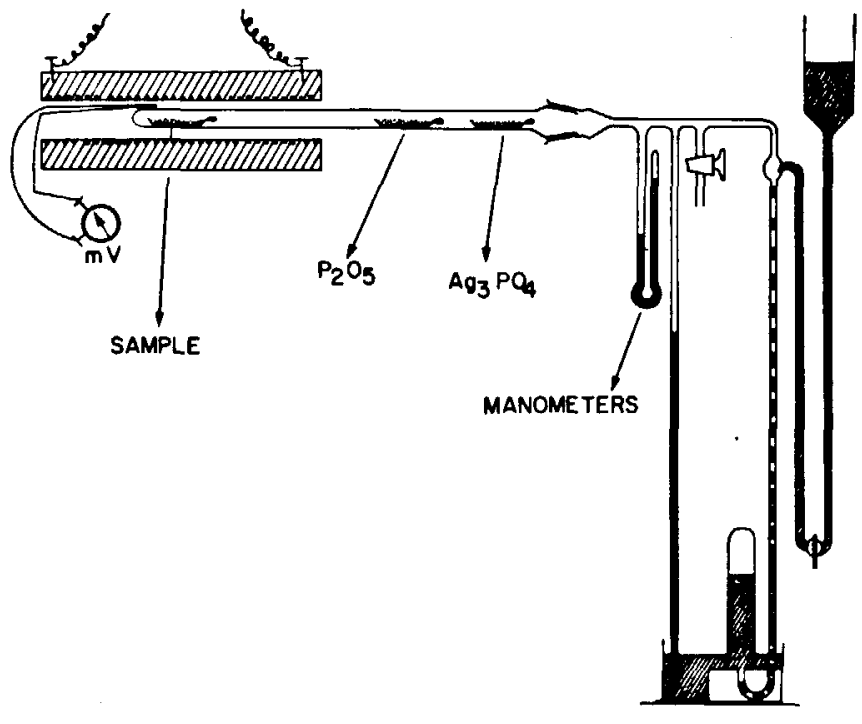

Fig. 1 - Apparatus showing the method used for extracting the gas from crushed rock samples.

components show that reducing conditions have prevailed during crystallization of the early-formed mineral prior to the ascent of the magma at the surface. The Mg-rich olivine which is the first mineral to be formed from a basaltic melt is enriched in $\mathrm{HCl}(>400 \mathrm{ppm})$ and in $\mathrm{CO}$ (1024 ppm) with respect to the bulk rock and the plagioclase mineral (Table 3). Early-formed plagioclase and olivine are depleted in $\mathrm{SO}_{2}$ (Table 3). Such depletion suggests that $\mathrm{SO}_{2}$ is concentrated in the residual liquid represented by the mesostasis. Sulfur dioxide could be formed by melting sulfide. The following reaction involving pyrite may generate the escape of $\mathrm{SO}_{2}$ :

$$
4 \mathrm{FeS}_{2}+11 \mathrm{O}_{2} \rightarrow 2 \mathrm{Fe}_{2} \mathrm{O}_{3}+8 \mathrm{SO}_{2}
$$

It is known (CzAMANSKe and Moore, 1977) that sulfide globules in basaltic rocks occur as a compound of iron, copper and zinc.

Other gaseous compounds could be liberated by the melting of Ca-bearing minerals. Calcite as a replacement product of pyroxene and olivine is often found in ocean floor basalts. $\mathrm{CO}_{2}$ could be liberated during the crystallization of plagioclase and clinopyroxene or it could result from secondary reactions during magmatic ascent.

Hydrogen chloride is another important gaseous phase encountered in ocean floor basalts. Table 4 shows that the amount of

TABLE 3 - Gas content in ppm. of the basaltic rocks collected by submersible samples (ARP) and by dredging (CH31) from the Rift Valley near $36^{\circ} 50^{\prime} \mathrm{N}$ in the Atlantic Ocean. CxHx corresponds to the content of hydrocarbons $\left(\mathrm{CH}_{4}, \mathrm{C}_{2} \mathrm{H}_{6}, \mathrm{C}_{3} \mathrm{H}_{8}, \mathrm{C}_{4} \mathrm{H}_{10}, \mathrm{C}_{2} \mathrm{H}_{2}, \mathrm{C}_{2} \mathrm{H}_{4}, \mathrm{C}_{3} \mathrm{H}_{6}, \mathrm{C}_{4} \mathrm{H}_{8}\right.$ and Benzene). $\mathrm{CxHx}$ was recalculated from volume to Weight Concentrations as $\mathrm{CH}_{4}$. (IGN) indicates the ignition loss at $1,000^{\circ} \mathrm{C}$.

\begin{tabular}{|c|c|c|c|c|c|c|c|c|c|c|}
\hline SAMPLE $\mathrm{N}^{\bullet}$ & TOTAL GAZ & $\mathrm{Hel}$ & $\mathrm{CO}_{2}$ & $\mathrm{co}$ & $\mathrm{H}_{2}$ & $\mathrm{SO}_{2}$ & $\mathrm{~N}_{2}$ & $\mathrm{CxHx}$ & IGN. & TYPE OF MATERIAL \\
\hline ARP73-7-1 & 917 & 1307 & 249 & 332 & 19 & 3 & 7 & 10.5 & 4400 & Olivine $B$. \\
\hline ARP $73-10-2$ & 1040 & 458 & 296 & 173 & 2 & 108 & 3 & 0.5 & 13200 & plag-pyrx-ol.B \\
\hline ARP $73-10-3$ & 1167 & 124 & 644 & 382 & 4 & 4 & 7 & 2 & 4800 & picritic B. \\
\hline ARP73-13-4 & .822 & 168 & 306 & 339 & 0.4 & - & 9 & - & 4100 & olivine $B$. \\
\hline ARP 74-10-16 & 674 & 190 & 195 & 254 & 11 & 21 & 2 & 1 & 4300 & olivine B. \\
\hline ARP74-11-17 & 1237 & 312 & 341 & 522 & 3 & 56 & 1 & 2 & 6600 & olivine B. \\
\hline ARP74-8-10 & 1261 & 523 & 427 & 188 & 3 & 117 & 2 & 1 & 7600 & plag-pyrx-ol.B \\
\hline ARP74-9-13 & 1094 & 428 & 270 & 218 & 1.5 & 175 & 1 & 0.5 & 6100 & plag- rich B. \\
\hline ARP $74-9-12$ & 717 & 240 & 191 & 222 & 5 & 58 & - & 1 & 4700 & olivine B. \\
\hline ARP74-7-8 & 1083 & 278 & 259 & 433 & 5 & 106 & 1 & 1 & 7400 & plag-pyrx-B. \\
\hline ARP $74-10-15$ & 979 & 422 & 263 & - & 4 & 75 & 213 & 2 & 5900 & olivine B. \\
\hline CH21-DR2-132 & 1254 & 366 & 425 & 373 & 10 & 3 & 53 & 24 & 5700 & pleg- rich B. \\
\hline $\begin{array}{l}\text { OLIVINE } \\
\text { CH3 I-DR8-10OD }\end{array}$ & 1616 & 423 & 130 & 1024 & 13 & - & 21 & 5 & 1200 & olivine \\
\hline $\begin{array}{l}\text { PLAGIOCLASE } \\
\text { CH31-DR2-132 }\end{array}$ & 571 & 105 & 82 & 359 & 7 & - & 12 & 6 & 800 & plagioclase \\
\hline ARP $74-11-18$ & 735 & 255 & 177 & - & 6 & 82 & 213 & 2 & & \\
\hline
\end{tabular}




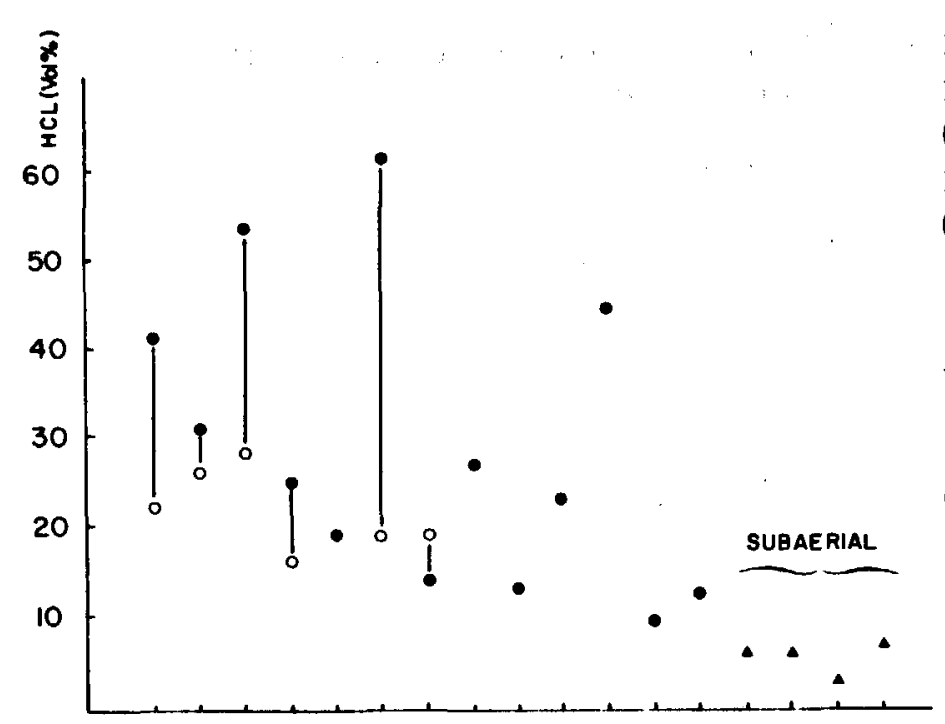

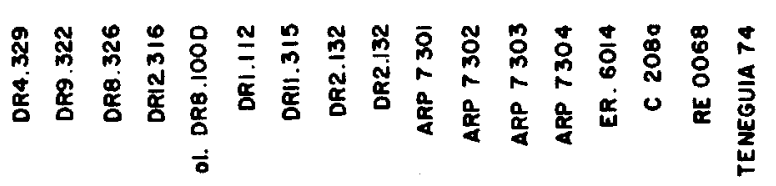

FIG. 2 - $\mathrm{HCl}$ (vol. \%) variation diagram of the various basaltic rocks collected from the ocean floor and from subaerial environment. Empty and full circles indicate glassy margin and interior of pillow flows respectively.

C 208: sample of basaltic rock from the Afar area (Ethiopia)

ER 6014: sample from the Erta'Alé Lava lake (Ethiopia).

RE 0068: sample from Piton de la Fournaise (Réunion island).

Teneguia: sample from Canarie island.

$\mathrm{HCl}$ reaches up to 1018 ppmin the interior of a pillow lava. The liberation of chlorine from the melting of chlorine-bearing minerals (e.g. chlorapatite, $\mathrm{Ca}_{5} \mathrm{Cl}_{3} \mathrm{O}_{12}$ ) could give rise to hydrogen chlorine abundantly observed during volcanic emanations. Non-metallic halogens reacting with water at the relatively low temperature of melting could form hydrogen chloride through the following reaction:

$$
\mathrm{PCl}_{3}+3 \mathrm{H}_{2} \mathrm{O} \rightarrow \mathrm{P}(\mathrm{OH})_{3}+3 \mathrm{HCl}
$$

As listed on Tables 3, 4 and 5, the total amount of gas expressed in part per million varies between about $600 \mathrm{ppm}$ to about $1500 \mathrm{ppm}$ for the ocean floor bulk rock analyses. Figure 2 and Table 4 show that there is a considerable difference between the gas content of subaqueous and subaerial volcanism. The range of variabil- ity in the total gas content of the basaltic rocks from the Afar region is much wider $(500-6500 \mathrm{ppm})$ than that of the submarine volcanism from the FAMOIS area (Table 5).

\section{$\mathrm{HCl}$ Content}

Hydrogen chloride is one of the major constituents of volcanic emanation. The relative low bounding forced of this ion, due to its low charge and large radius, implies that chlorine is mainly concentrated in late magmatic solutions. An igneous mineral which might include chlorine is a chlorapatite $\left(\mathrm{Ca}_{5} 4 \mathrm{Cl} \mathrm{P}_{3} \mathrm{O}_{12}\right)$. Needles of apatite are often found in basaltic rock associated with plagioclase crystals. It is also likely that cations such as $\mathrm{Na}$ and $\mathrm{K}$ could form chloride compounds in aqueous solutions.

$\mathrm{HCl}$ is one of the major gas components of the rocks analysed and its concentration expressed in weight of the bulk rock varies between about $100 \mathrm{ppm}$ to about $1000 \mathrm{ppm}$ (Table 3, 4). There is a difference between the $\mathrm{HCl}$ content of the olivine phenocryst analysed (423 ppm) and that of the plagioclase phenocryst (100 ppm) (Table 3). In general, the $\mathrm{HCl}$ content of the pillow lava glassy margin is lower than that of the interior, except for sample DR9-322 (Table 4, Fig. 2).

\section{$\mathrm{CO}_{2}$ and $\mathrm{CO}$ Content}

The $\mathrm{CO}_{2}$ content of the bulk basaltic rocks varies between 200 and $900 \mathrm{ppm}$ (Table 3,4 ) which is similar to that found $\left(\mathrm{CO}_{2}=400-900 \mathrm{ppm}\right)$ by MoORE et $a l$., (1977). The reduced state of carbon in the form of $\mathrm{CO}$ is mainly concentrated in the mafic constituents. The olivine phenocrysts analysed contain the highest value of $\mathrm{CO}$ (up to $1024 \mathrm{ppm}$ ) (Table 3).

The concentration of both $\mathrm{CO}$ and $\mathrm{CO}_{2}$ in basaltic rocks varies according to the degree of crystallinity of the rocks which controls the relative abundance of the gaseous phase. The specimens which are the least crystalline, such as those deprived of 
TABLE 4 - Gas content expressed in ppm of the pillow lava glassy margin and of the most crystalline interior of the rocks collected from the Rift Valley in the FAMOUS area near $36^{\circ} \mathrm{N}$ in the Atlantic Ocean.

\begin{tabular}{|c|c|c|c|c|c|c|c|c|c|c|}
\hline SAMPLE $N^{\circ}$ & TOTAL GAS & $\mathrm{Hcl}$ & $\mathrm{CO}_{2}$ & co & $\mathrm{H}_{2}$ & $\mathrm{SO}_{2}$ & $\mathrm{~N}_{2}$ & CxHx & IGN. & TYPE OF ROCK \\
\hline $\begin{array}{l}\text { CH31-DR4 } \\
\text { 329-GLASS } \\
\text { INTERIOR }\end{array}$ & $\begin{array}{r}1044 \\
993\end{array}$ & $\begin{array}{l}332 \\
544\end{array}$ & $\begin{array}{l}510 \\
236\end{array}$ & $\begin{array}{l}170 \\
140\end{array}$ & $\begin{array}{l}27 \\
17\end{array}$ & $\begin{array}{l}2 \\
\operatorname{tr}\end{array}$ & - & $\begin{array}{l}3 \\
4\end{array}$ & $\begin{array}{l}4600 \\
4100\end{array}$ & $\begin{array}{l}\text { Olivine } \\
\text { Basalt }\end{array}$ \\
\hline $\begin{array}{l}\text { CH31-DR9 } \\
322-G L A S S\end{array}$ & 1195 & 533 & 307 & 304 & 44 & - & 2 & 5 & 400 & Olivine \\
\hline INTERIOR & 1033 & 426 & 263 & 305 & 17 & 20 & - & 2 & 3800 & Basalt \\
\hline $\begin{array}{l}\text { CH31-DRI2 } \\
316 \text {-GLASS }\end{array}$ & 981 & 234 & 153 & 260 & 25 & 2 & - & 7 & 3300 & Picritic \\
\hline INTERIOR & 750 & 265 & 182 & 281 & 17 & tr & - & 5 & 2800 & Basalt \\
\hline $\begin{array}{l}\text { CH31-DRI } \\
112-\text { GLASS }\end{array}$ & $1 ! 03$ & 270 & 610 & 189 & 22 & 6 & 3 & 4 & 4300 & Olivine \\
\hline INTERIOR & 1544 & 1018 & 281 & 187 & 8 & 48 & - & 1 & 5600 & Basalt \\
\hline $\begin{array}{l}\text { CH3-DR8 } \\
\text { 326-GLASS }\end{array}$ & 1118 & 341 & 556 & 207 & 7 & tr & 3 & 4 & & Picritic \\
\hline INTERIOR & 1001 & 614 & 223 & 147 & 8 & 7 & - & 3 & 4500 & Basalt \\
\hline $\begin{array}{l}\text { ARP } 74-7 \\
\text { S-GLASS }\end{array}$ & 940 & 144 & 594 & 154 & 29 & 13 & $t r$ & 6 & 6000 & Plag-pyrx \\
\hline INTERIOR & 981 & 278 & 386 & 239 & 7 & 32 & 34 & 5 & 14700 & Basalt \\
\hline $\begin{array}{l}\text { ARP } 74-12-19 \\
\text { CLASS }\end{array}$ & 1239 & 250 & 214 & 697 & 26 & 45 & 6 & 1 & 4100 & Olivine B. \\
\hline INTERIUR & 1528 & 345 & 247 & 838 & 17 & 21 & 52 & 2 & 7000 & \\
\hline $\begin{array}{l}\text { CH } 31-D R \quad 11 \\
315 \text { Y CLASS }\end{array}$ & 1543 & 405 & 931 & 163 & 36 & 6 & - & 2 & & Olivine $B$. \\
\hline INTER I OR & 1154 & 183 & 585 & 206 & 16 & 161 & - & 3 & & \\
\hline
\end{tabular}

early formed minerals, have the lowest $\mathrm{CO} / \mathrm{CO}_{2}$ ratio when compared with those having abundant phenocrystal phases (sample 10-16, 13-4, 132 and $10-3$ ) or a well crystallized matrix (sample 7-8) (Fig. 3 ). Another factor controlling the distribution of $\mathrm{CO} / \mathrm{CO}_{2}$ ratio is the bulk rock compositional variation as will be discussed further on. The most glassy rocks such as samples $315 \mathrm{y}$ and $315 \mathrm{x}$ are among the most enriched in $\mathrm{CO}_{2}$ content (931 ppm) (Table 3). It is likely that the increase of the $\mathrm{CO}_{2}$ content is related to the degree of

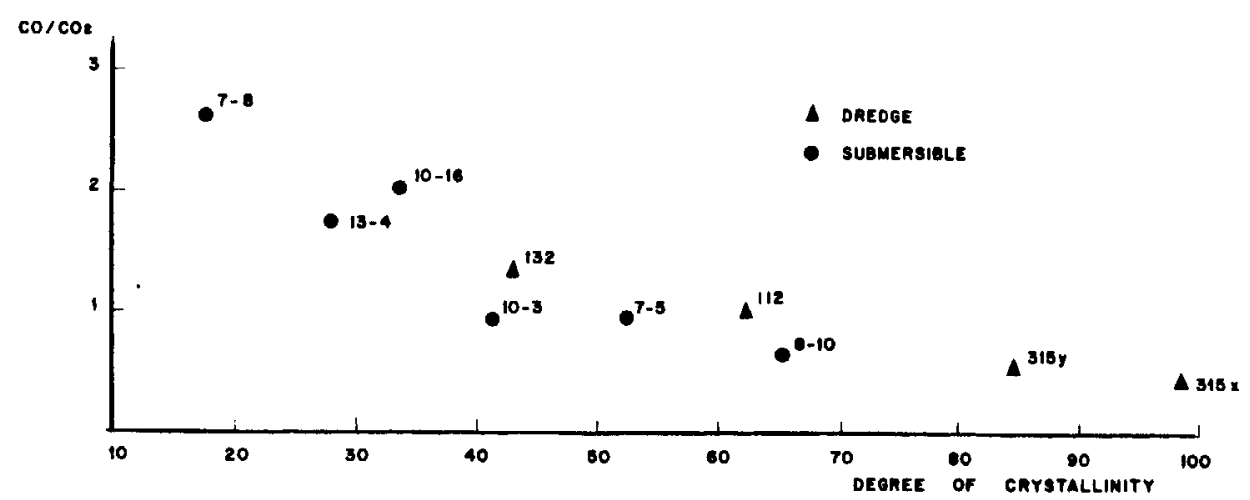

FIG. $3-\mathrm{CO} / \mathrm{CO}_{2}$ versus degree of crystallinity variation diagram of dredged ( $\Delta$ ) and submersible samples ( $(-$ ). The degree of crystallinity corresponds here to the amount (vol. \%) of dark mesostasis comprising glass, cryptocrystalline aggregate and iron oxide granules. vesicularity. Often, basaltic pillow lava fragments from the FAMOUS area show a narrow rim abundantly vesiculated near the glassy margin of the rock (BIDEAU et al., 1976). However this is not a general rule and vesicles may be sparsely distributed throughout the pillow flow.

\section{$H_{2}$ Content}

There is a striking difference between subaerial and suaqueous volcanism as far 


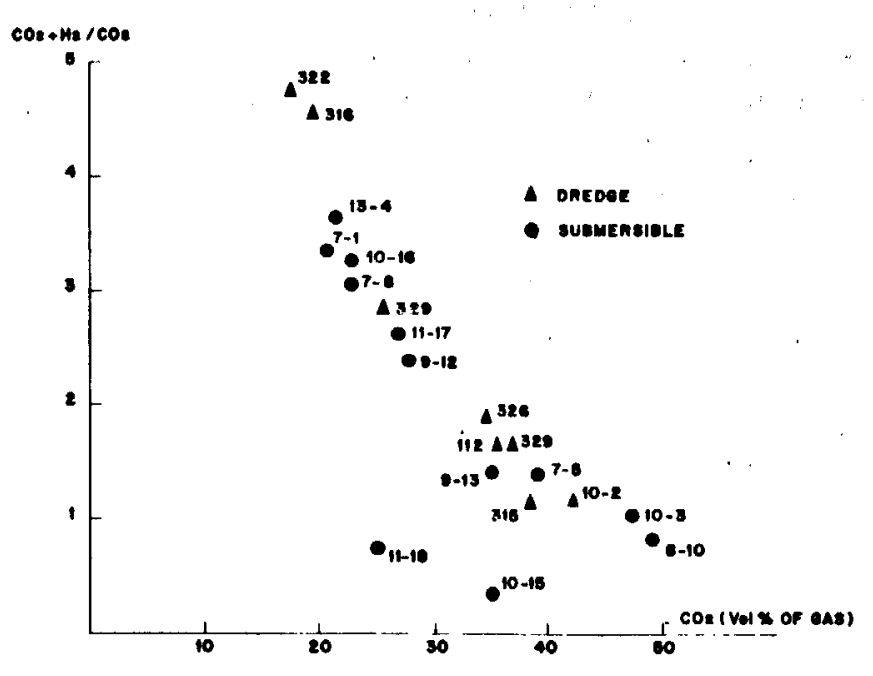

FIG. 4 - $\mathrm{CO}+\mathrm{H}_{2} / \mathrm{CO}_{2}$ versus $\mathrm{CO}_{2}$ (vol. \% of gas) variation diagram, of basaltic rocks from the Rift Valley of the Mid-Atlantic Ridge near $36^{\circ} 50^{\prime} \mathrm{N}$.

as the $\mathrm{H}_{2}$ content is concerned. The subaerial volcanics from the Afar and from Réunion Island show a considerably low $\mathrm{H}_{2}$ content $(<5 \mathrm{ppm})$ when compared to deep ocean floor volcanism $\left(\mathrm{H}_{2}=\right.$ up to 45 ppm) (Tables 3,5 ). The $\mathrm{H}_{2}$ content is included in both early formed crystals such as olivine $\left(\mathrm{H}_{2}=13 \mathrm{ppm}\right)$ and, in smaller amounts, in pagioclase $\left(\mathrm{H}_{2}=7 \mathrm{ppm}\right)$ (Table 3). The relative amount of $\mathrm{H}_{2}$ together with the $\mathrm{CO} / \mathrm{CO}_{2}$ ratio show a covariance. This is probably related to the degree of oxydation of the bulk rock. Indeed it is observed that the $\mathrm{H}_{2}+\mathrm{CO} / \mathrm{CO}_{2}$ varies from the crystalline interior to the glassy margins (Fig. 5). The difference in the oxydation state of the carbon between interior bulk-rock composition and the outer glassy margin suggests a convective fluidal circulation due to a temperature gradient during subaqueous cooling. It is unlikely that there is an exchange between sea water and the glassy margin of pillow lava during chilling, since the rela- tive amount of $\mathrm{H}_{2}$ content in the bulk rock and that of the early mineral phases crystallized are about the same (sample $\mathrm{CH}$ 31-DR 2-132; Table 3, 4).

\section{$\mathrm{SO}_{2}$ Content}

Oceanic rocks are believed to have retained their sulfur content while subaerially erupted volcanic rocks having a generally lower sulfur content (MOORE and FABBRI, 1971) might have lost it in the atmosphere during eruption. Analyses of the outer'glassy margins of basaltic rock from the ocean floor show a sulfur content of 840-1370 ppm (MOORE and FABRI, 1971; Czamanske and MoORE, 1977). Sulfur in these rocks occurs as sulfide globules (MOORE and CALK, 1971) or probably as interstitial compounds such as pyrite, chalcopyrite, etc., in the matrix.

In this study, the analysed gaseous sulfur expressed as $\mathrm{SO}_{2}$ does not represent the total sulfur content of the rock but is the amount of the gaseous phase left after the solification of the sulfur minerals of the bulk rock. The $\mathrm{SO}_{2}$ content of the basaltic rocks collected from the same general area as those described by CzAMANSKE and MOORE (1977) varies from nil to up to about $161 \mathrm{ppm}$ of sulfur (Table 4 ). The discrepancy between the sulfur content of our analysed rocks and that determined by the bulk analyses of glass (CZAMANSKE and MOORE, 1977) is due to the phase difference. The extraction of the gaseous phase $\mathrm{SO}_{2}$ included as gas bubbles in minerals or in the mesostasis of the rock is obtained by heating the samples to less than $1000^{\circ} \mathrm{C}$, whereas the melting point of the iron and $\mathrm{Cu}$ sulfides is above $1000^{\circ} \mathrm{C}$. Hence the measure of sulfur obtained with the present method does not give the total amount of the element in the bulk rock.

TABLE 5 - Gas analyses expressed in ppm of basaltic rocks from the Afar region in Ethiopia.

\begin{tabular}{|c|c|c|c|c|c|c|c|c|c|c|c|c|}
\hline SAMPLE $\mathrm{N}^{\circ}$ & TOTAL GAS & $\mathrm{HCl}$ & $\infty_{2}$ & $\infty$ & $\mathrm{H}_{2}$ & $\mathrm{SO}_{2}$ & $\mathrm{~N}_{2} \mathrm{O}$ & $\mathrm{N}_{2}$ & NO & $\overline{C x A y}$ & IQN. & ROCK TYPES \\
\hline$C-230$ & 2453 & 118 & 747 & 124 & 3 & 1434 & 8 & 15 & 4 & & 6000 & Olivine basalt \\
\hline $\mathrm{OH}-48$ & 4614 & 13 & 2088 & 23 & 4 & 2397 & 4 & 74 & 11 & & 7600 & Picritic basalt \\
\hline C 227 & 6444 & 523 & 1435 & 103 & 0 & 4378 & 5 & & & & 9400 & Olivine basalt \\
\hline C 201 & 3965 & 31 & 3540 & 134 & 0 & 248 & 4 & & 8 & & 6900 & Olivine basalt \\
\hline ER 6014 & 535 & 31 & 238 & 169 & 0.8 & 48. & & & & 5 & 2000 & Plagioclase basalt \\
\hline
\end{tabular}




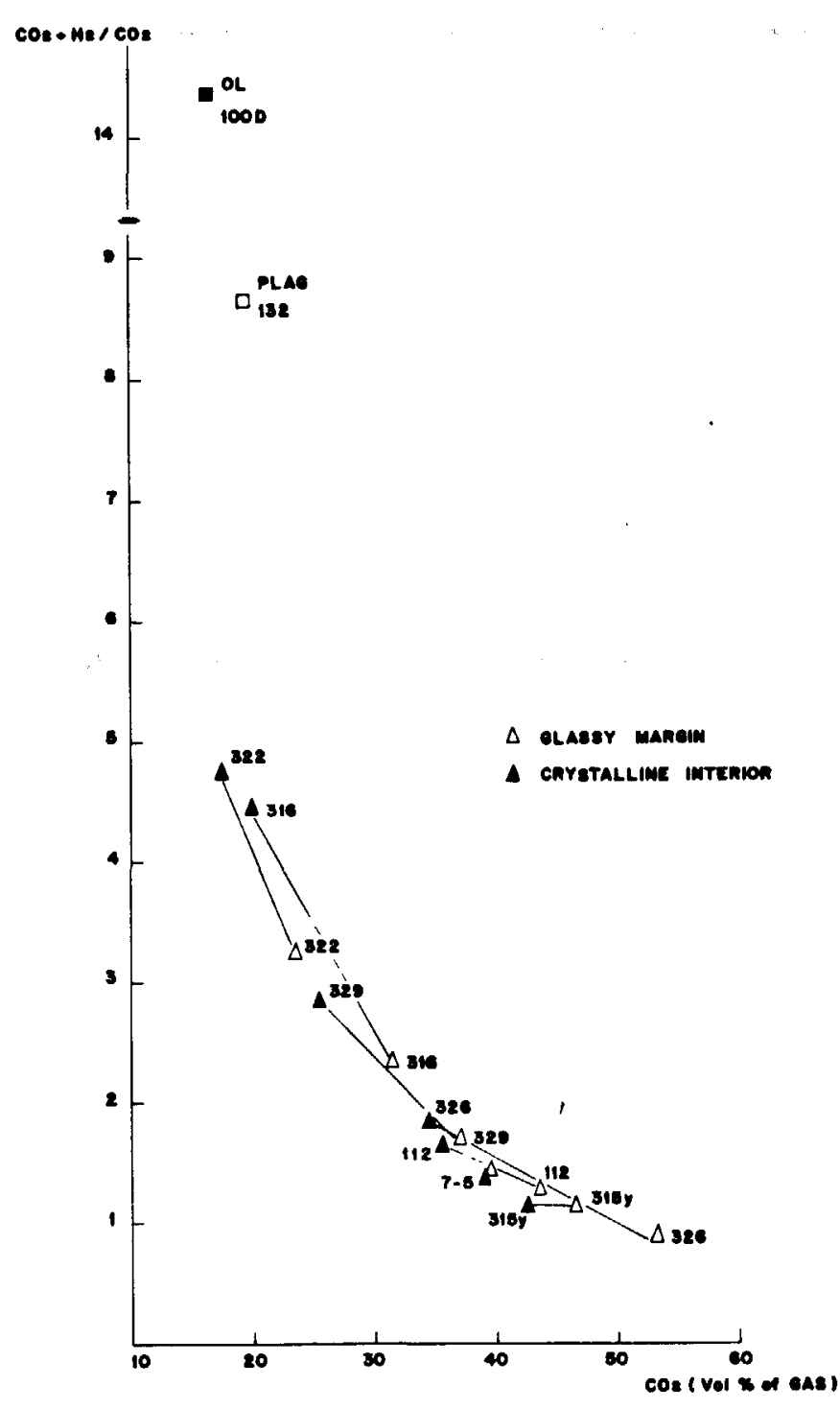

FIG. 5 - $\mathrm{CO}+\mathrm{H}_{2} / \mathrm{CO}_{2}$ versus $\mathrm{CO}_{2}$ (vol. \% of gas) variation diagram of basaltic rocks from the Rift Valley of the Mid-Atlantic Ridge near $36^{\circ} 50^{\prime} \mathrm{N}$. The glassy margin $(\triangle)$ and the most crystalline interior $(\boldsymbol{A})$ for each individual sample are related together by a tie-line.

Since no detectable amount of sulfur was found in the plagioclase and olivine phenocrysts' analyses (samples 112 and $100 \mathrm{D}$; Table 3), it is assumed that the sulfur content is concentrated in the residual melt during crystallization or as sulfide globules made up of $\mathrm{Fe}-\mathrm{Ni}-\mathrm{Cu}$ $\mathrm{S}$ association (CZAMANSKE and MOORE, 1977).

The $\mathrm{SO}_{2}$ content of the volcanics from the Rift Valley near $36^{\circ} 50^{\prime} \mathrm{N}$ is much lower $(<200 \mathrm{ppm})$ than that of the samples analysed from the subaerial volcanism of
Afar (samples 230, 48, 227) where the $\mathrm{SO}_{2}$ content reaches up to $1500-4000 \mathrm{ppm}$ (Table 3, 5). However other samples $(6014,201)$ have an $\mathrm{SO}_{2}$ content $(<250 \mathrm{ppm})$ as low as that found from the youngest volcanic edifices of the Rift valley inner floor (Tables 3,5 ). The initial magmatic sulfur content is transformed into $\mathrm{SO}_{2}$ at a relatively shallow depth, late during volcanic activity. The $\mathrm{CO} / \mathrm{CO}_{2}-\mathrm{H}_{2}$ $\mathrm{SO}_{2}$ ternary diagram shows the plot of the various types of basalts from the ocean floor in comparison with those from Afar (Fig. 6).

The composition of most ocean floor basaltic rocks (olivine basalt, picritic basalt, highly phyric plagioclase basalt and plagioclase-pyroxene-olivine basalt) plots in the $\mathrm{CO}$ and $\mathrm{H}_{2}$ side. A few of the most fractionated rocks (samples 8-10, 10-2 and 9-13) are closer to the $\mathrm{SO}_{2}$ corner. The composition of the subaerial volcanics from both Afar and the Azores plot on the $\mathrm{SO}_{2}$ corner.

The $\mathrm{SO}_{2}$ content does not show any systematic variation between the pillow lava glassy margins and their corresponding interior (Table 4). However there is a consistent $\mathrm{SiO}_{2}$ variation observed with the compositional changes of the bulk rock.

\section{RELATIONSHIP BETWEEN GAS \\ CONTENT AND BULK ROCK \\ COMPOSITIONAL VARIATIONS}

The different gaseous phases analysed were recalculated from volume to weight content in order to compare with the major oxide constituents of the rocks. There is no clear realtionship between the various rock types encountered in the Rift Valley and the total amount of gas present. The total amount of gas content is more or less constant between the various rock types and varies from 500 to about $1600 \mathrm{ppm}$ (Table 1, Fig. 7).

However there is a continuous $\mathrm{CO} / \mathrm{CO}_{2}$ ratio change with compositional variation of the rock. The composition change is expressed in terms of $\mathrm{FeO}^{*} / \mathrm{MgO}$ ratio where the total $\mathrm{Fe}$ is calculated as $\mathrm{FeO}$ as 


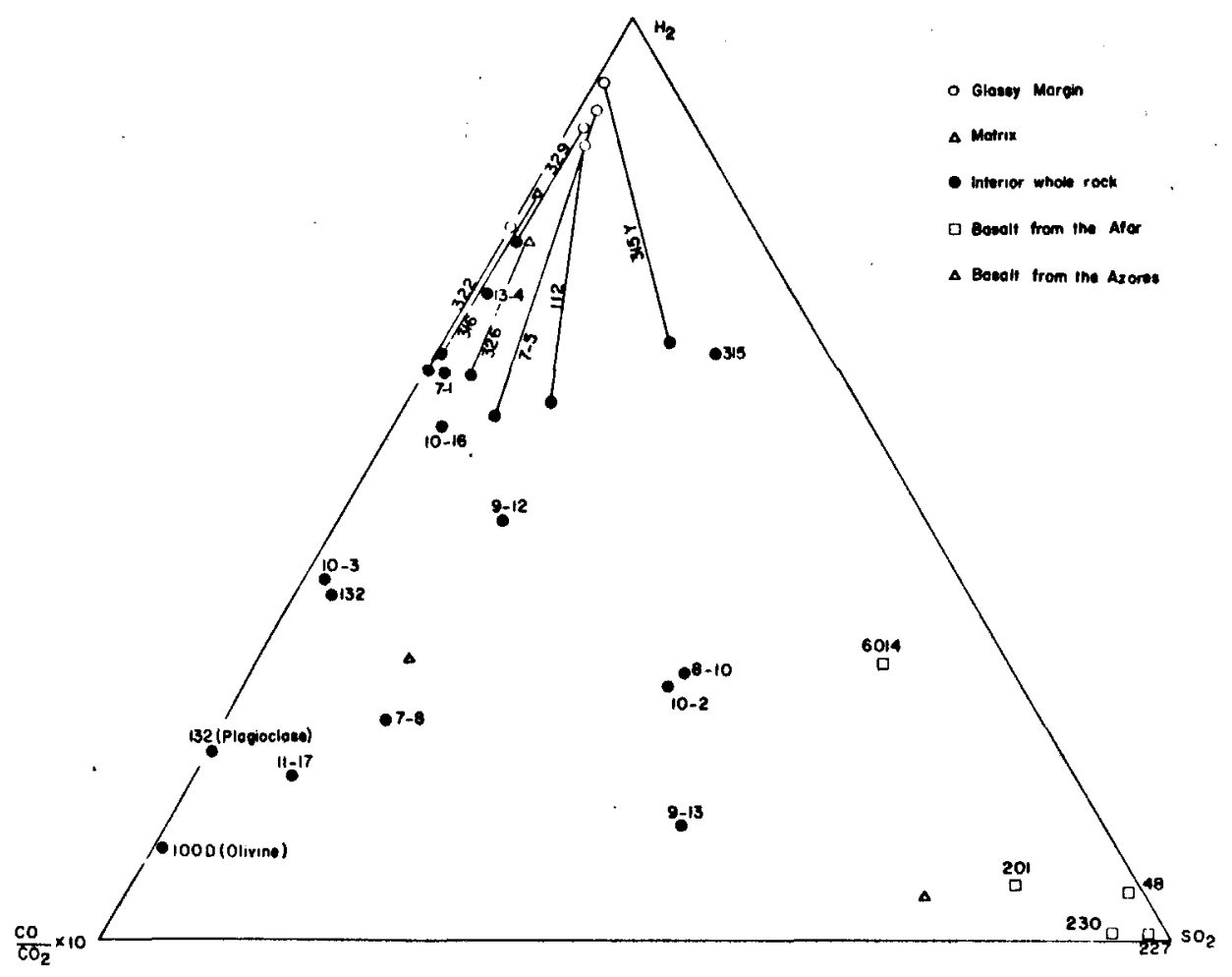

FIG. 6 - Ternary diagram expressed as $\mathrm{CO} / \mathrm{CO}_{2} \times 10-\mathrm{H}_{2}-\mathrm{SO}_{2}$, showing the plot of early-formed mineral phases and of the various types of basaltic rocks collected from the Rift Valley near $36^{\circ} 50^{\prime} \mathrm{N}$ in the Atlantic Ocean. The black dots indicate the interior bulk rock composition of the pillow lava fragment, while the empty circles are the data of the corresponding glassy margin. In addition, the plots of subaerial volcanics, from Afar $(\square)$ and the Azores islands $(\triangle)$ (CHAIGNEAU, 1975) are shown.

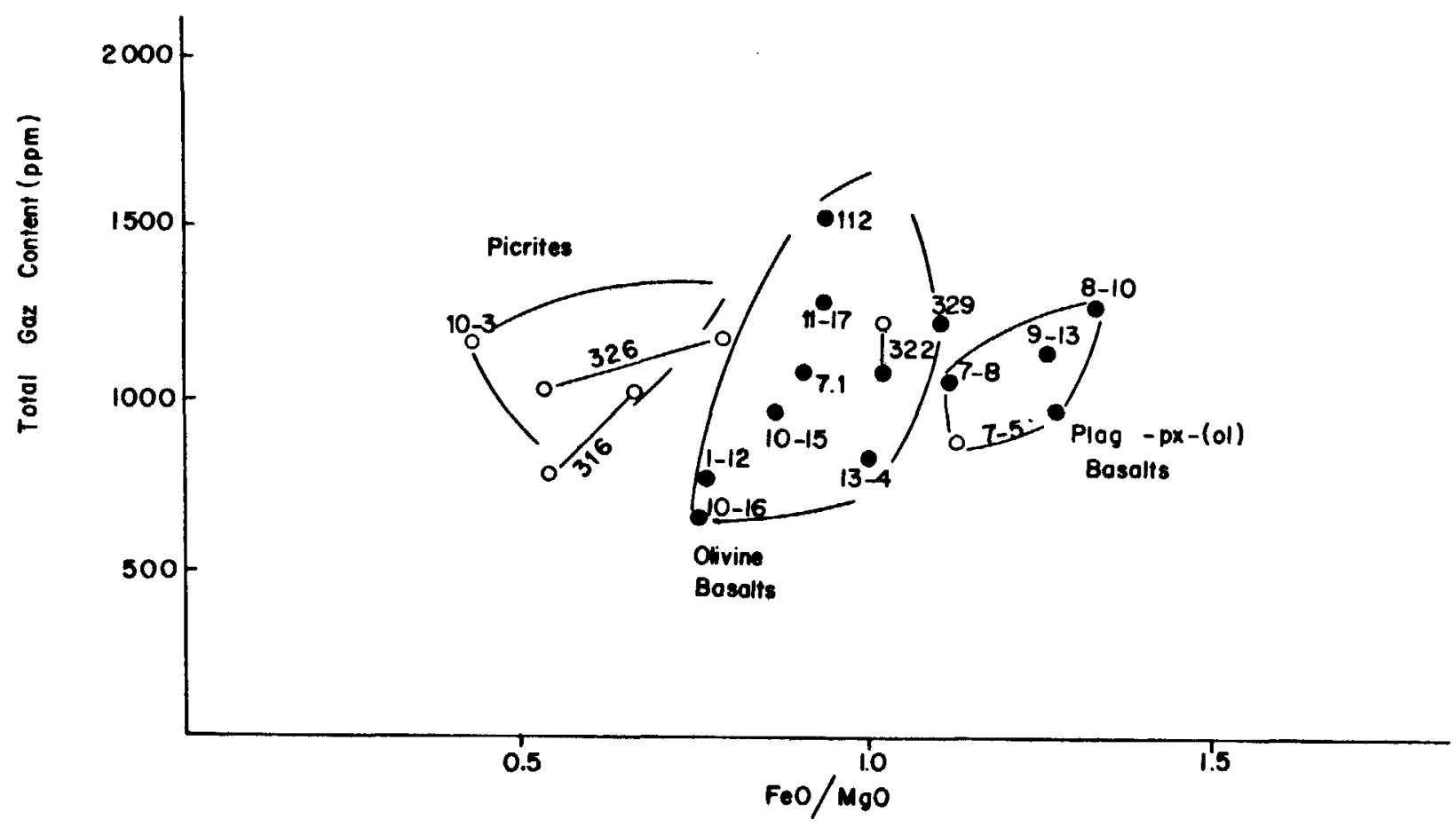

Fig. 7 - Total gas content espressed in $\mathrm{ppm}$ versus $\mathrm{FeO}^{*} / \mathrm{MgO}$ variation diagram of various basaltic rocks from the Mid-Atlantic Ridge Rift Valley near $36^{\circ} \mathrm{N}$. Black dots are the interior of pillow lava fragments and empty circles are the glassy margin. 
shown in Figure 7. The picritic basalts having an $\mathrm{FeO}^{*} / \mathrm{MgO}$ ratio of less than 0.7 are also among the rocks the most enriched in the $\mathrm{CO}$ content. The plagioclasepyroxene basalts are among the most rich in $\mathrm{CO}_{2}$ content. The plagioclase-rich rocks and the olivine basalts have intermediate values (Fig. 7). The increase of the CO$\mathrm{CO}_{2}$ oxidation state is probably due to a two fold process: (1) A residual fractionated liquid which has a higher $\mathrm{CO}_{2}$ content than the refractory material (crystalline phase) and (2) the degree of rock crystallinity which also plays an important role and whether or not early crystalline phases solidified prior to the eruption will influence the $\mathrm{CO} / \mathrm{CO}_{2}$ ratio. Indeed two trends of $\mathrm{CO} / \mathrm{CO}_{2}$ ratio versus $\mathrm{FeO} / \mathrm{MgO}$ variations are observed in Fig. 8. Both the aphyric and the phyric trends follow a decrease in $\mathrm{CO} / \mathrm{CO}_{2}$ with an increase in $\mathrm{FeO} / \mathrm{MgO}$ ratios going from picritic rocks depleted in $\mathrm{CO}_{2}$ content to the plagioclase-pyroxene basalt enriched in $\mathrm{CO}_{2}$ content (Table 2, 3; Fig. 8 ). The phyric trend is represented by rocks having more than 10 percent early formed mineral phases, while the aphyric trend refers to rocks having less than 5\% phenocrystal material.

Sulfur is another component showing variation with bulk rock compositional changes. There is a positive correlation between the $\mathrm{FeO}^{*} / \mathrm{MgO}$ ratio and that of the $\mathrm{SO}_{2}$ content (Fig. 9). There is a positive correlation between the $\mathrm{TiO}_{2}$, the $\mathrm{FeO}^{*} / \mathrm{MgO}$ and the $\mathrm{SO}_{2}$ content of the various types of basaltic rocks. The highest $\mathrm{SO}_{2} \quad(100-150 \mathrm{ppm})$ content is found among the fractionated basalt located at the margins of the inner floor (samples 913; 8-10; 10-2 and 7-8) (Fig. 9) while the

o Glossy Rocks

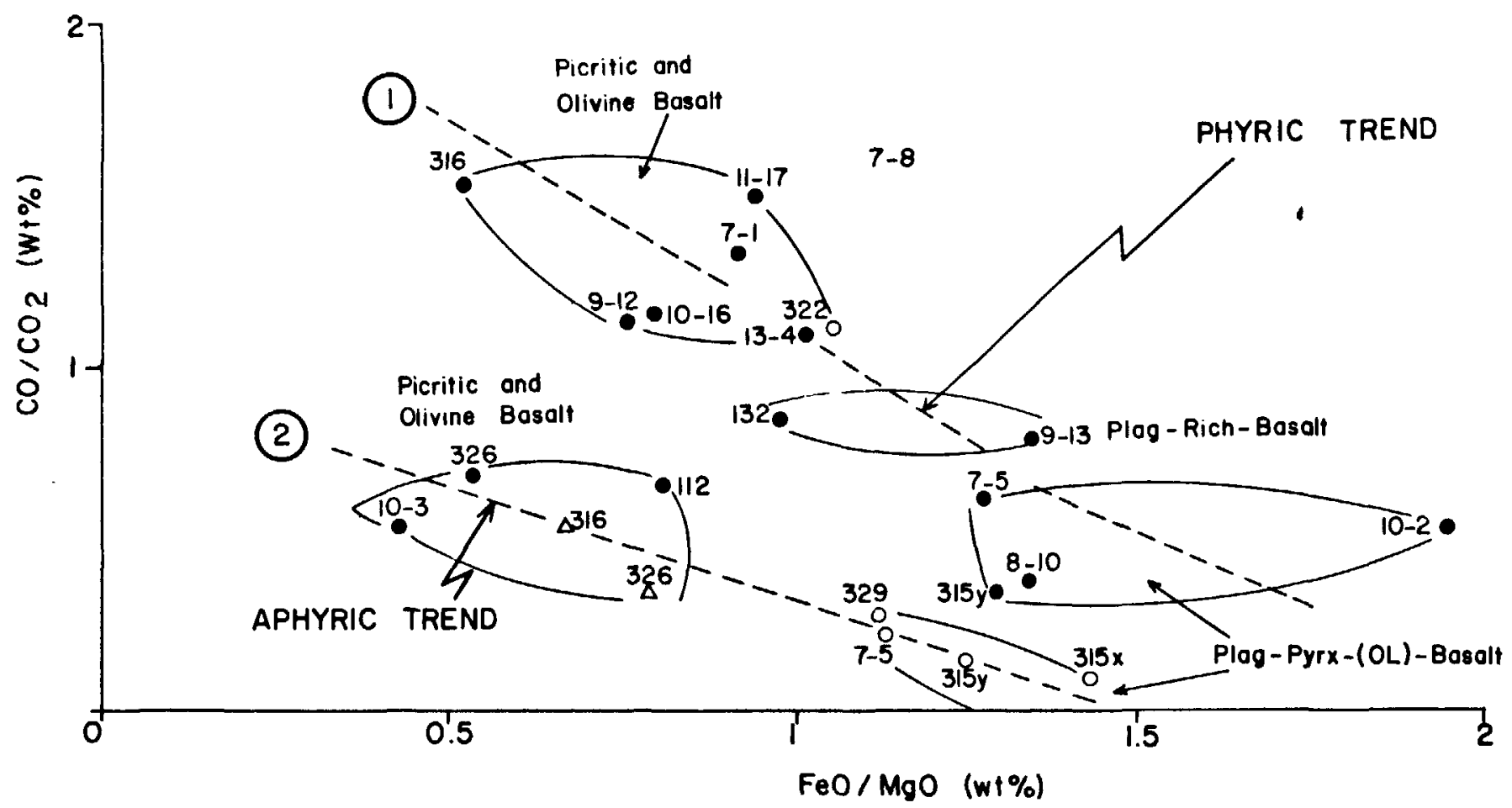

FIG. 8 - $\mathrm{FeO} / \mathrm{MgO}$ - $\mathrm{CO} / \mathrm{CO}$. variation diagram of the various rock types encountered on the Rift Valley of the Mid-Atlantic Ridge near $36^{\circ} 50^{\prime} \mathrm{N}$. The Mid-Atlantici Ridge near $36^{\circ} 50^{\prime} \mathrm{N}$. The black dots indicate the data from the most crystalline interior of the pillow lava fragments. The empty circles and the triangles represent the least crystalline portion or aphyric rock. Dash lines 1 and 2 represent the average trend of the phyric and aphyric rocks respectively. The numbers near each plotted sign indicate the site and the sample numbers. 
lowest values in $\mathrm{SO}_{2}$ content $(<100 \mathrm{ppm})$ occur on the centrally located volcanic hill, Mount of Venus (samples 10-16; 11$17 ; 9-12 ; 13-4 ; 7-1 ; 10-3)$ or on Mount Mercury (sample $332 ; 12-19$ ) which are made up essentially of olivine basalt (Fig. 9).

The importance of knowing the total amount of gases included in a relative fresh rock might help to speculate on the volume of gas concentrated during volcanic eruption on an accreting plate boundary region. Thus, if we take the example of Mount of Venus which represents the most recent volcanic edifice built up within the last 15000 years, it is possible to estimate the volume of gas trapped in the area. Assuming that Mount of Venus has the shape of a parallelogram, with an average height above the inner floor of about 250 meters, a lenght of $2 \mathrm{~km}$ and a width of $1 \mathrm{~km}$, the volume of material erupted is of $500 \times 10^{6} \mathrm{~m}^{3}$. Taking a density of about $2.82 \mathrm{~g} / \mathrm{cm}^{3}$ for basaltic rocks from the FAMOUS area, the amount of volcanics in the area of Mount of Venus corresponds to
$1.41 \times 10^{9}$ tons of rocks. The average volume of gas included in these volcanics is $74 \mathrm{ml} / 100 \mathrm{~g}$. Hence the total amount of gas included into the basaltic rocks forming Mount of Venus is in the order of $10^{9} \mathrm{~m}^{3}$. However this figure cannot be extrapolated to older age crust because it is likely that the gaseous phases trapped into fresh rock might escape with time with alteration. Tectonic motions followed by fragmentation of the oceanic crust might influence the release of gas into the hydrosphere.

\section{CONCLUSIONS}

The gas extracted from basaltic rocks from the Rift Valley near $36^{\circ} \mathrm{N}$ in the Atlantic Ocean represents the gaseous phases included in both the minerals and the groundmass of the rock. The total amount of gas content in subaqueous volcanics from the Rift Valley is comprised between $500 \mathrm{ppm}$ and $1600 \mathrm{ppm}$. The major gases detected are as follows: $\mathrm{CO}_{2}$ (150$650 \mathrm{ppm}), \mathrm{CO}$ (150-800 ppm), HCl (100-

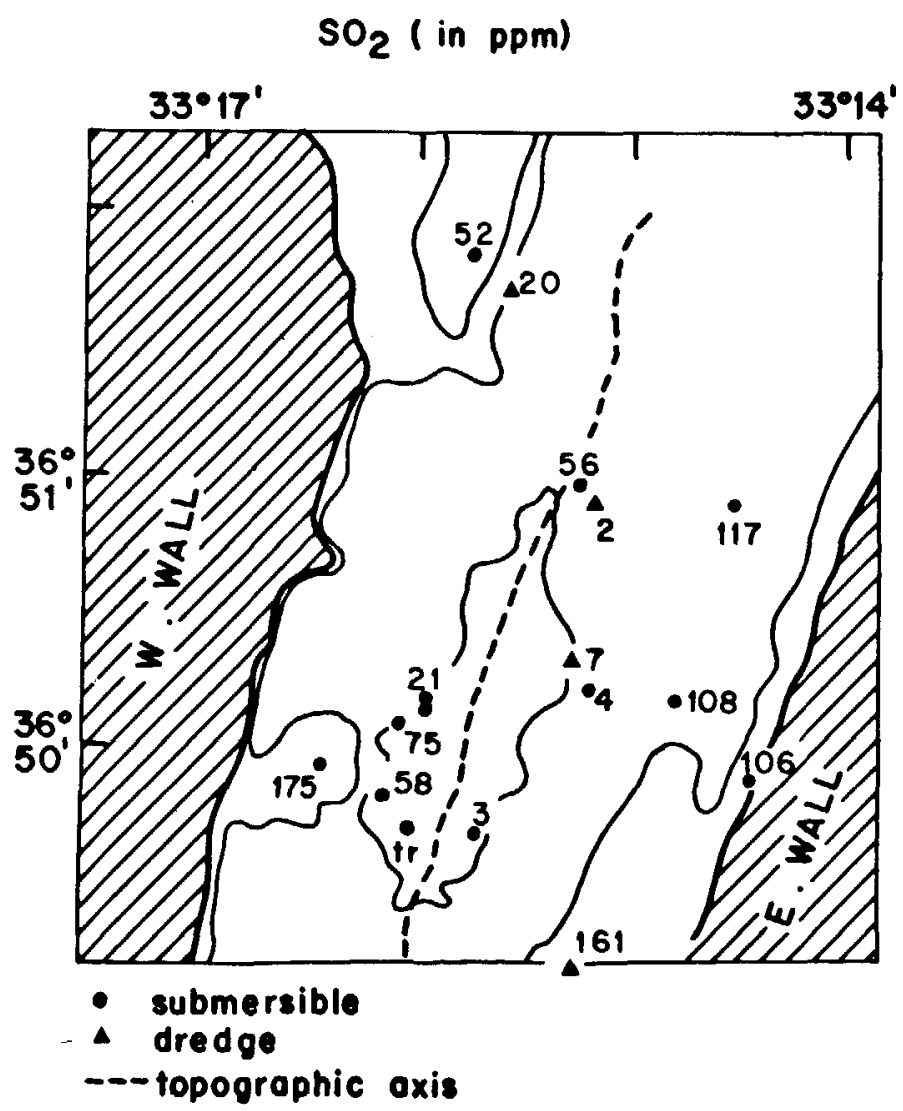

$\frac{\mathrm{FeO}}{\mathrm{MgO}} \times 100$ (Bulk rock)

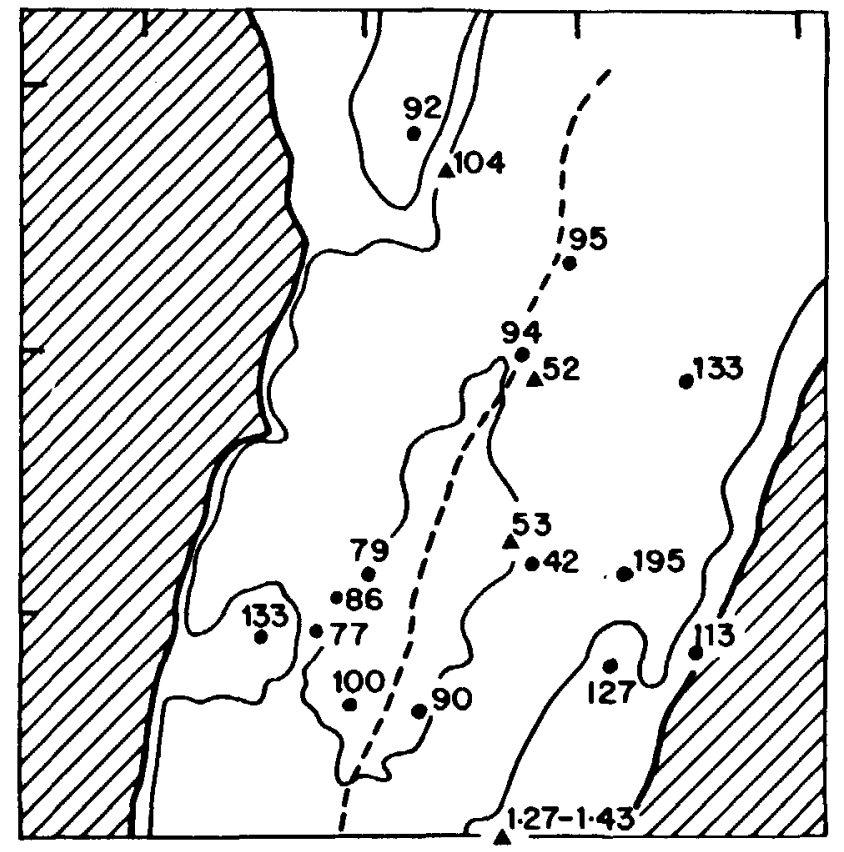

Fig. $9-\mathrm{SO}_{2}$ (in ppm) and $\mathrm{FeO} / \mathrm{MgO}$ (bulk rock) distribution of basaltic rocks recovered from the inner floor of the Rift Valley near $36^{\circ} 50^{\prime} \mathrm{N}$ in the Atlantic Ocean. 

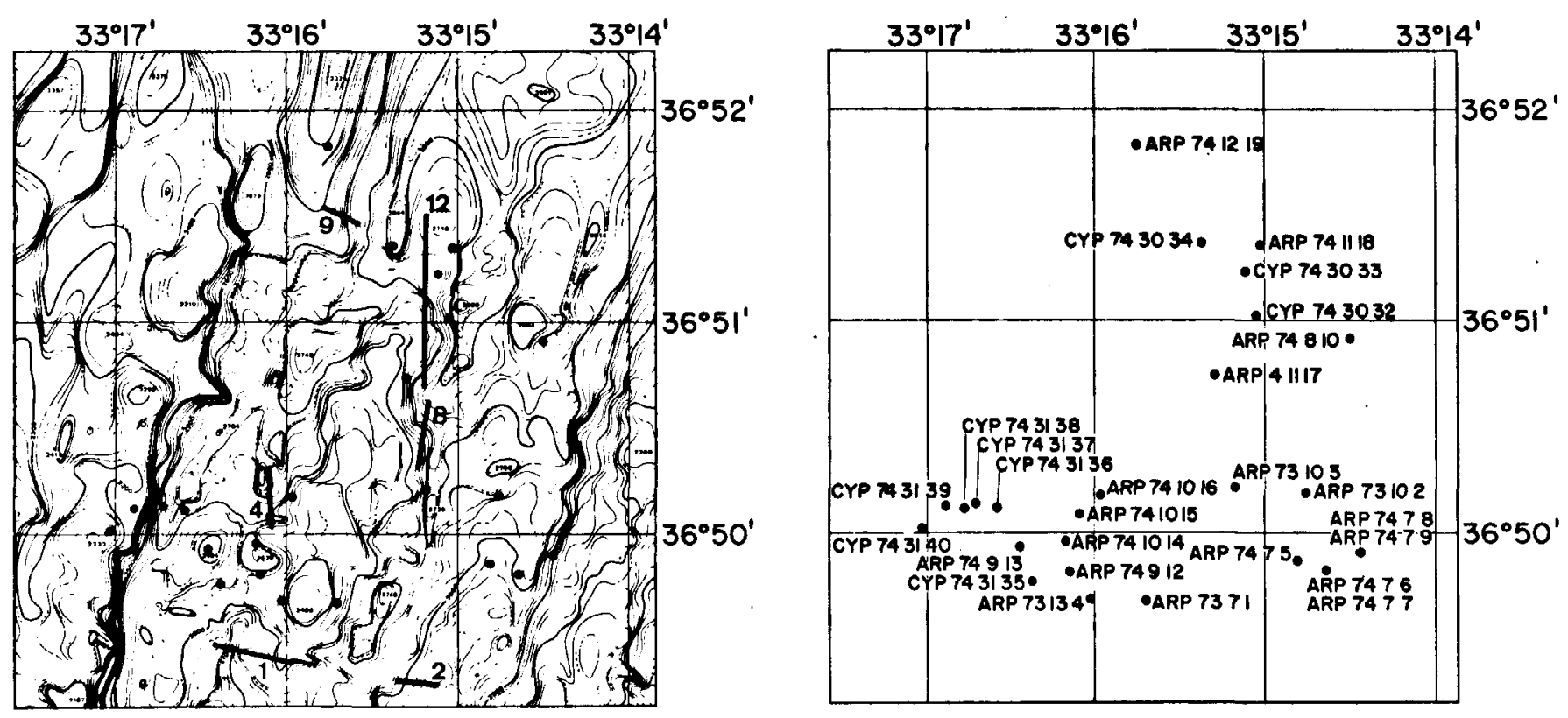

FIG. 10 - Bathymetric map of the Rift Valley after RENARD et. al. (1975) near $36^{\circ} 50^{\prime} \mathrm{N}$ on the Mid Atlantic Ridge showing the sample locations.

The black dots represent the rock samples collected by submersibles (Cyana - CYP and Archimède $=\mathrm{ARP})$, the heavy lines are the dredge hauls (CH31 - DR 1, 2, etc...).

$1000 \mathrm{ppm}), \mathrm{H}_{2}(0-500 \mathrm{ppm})$ and $\mathrm{SO}_{2}(0-$ $175 \mathrm{ppm})$. Traces and minor amounts of $\mathrm{N}_{2}$ and hydrocarbons were also detected.

The early-formed mineral phases such as olivine and plagioclase are enriched in the $\mathrm{CO} / \mathrm{CO}_{2}$ ratio with respect to their bulk rock composition. The concentration of magmatic gas is dependent on the bulk rock composition and its degree of crystallinity. Thus the increase in the ratio of $\mathrm{CO} / \mathrm{CO}_{2}$ is directly proportional to the increase in the relative amount of early-formed mineral phases. A basaltic ock with abundant matrix material (mesostasis) will have the largest $\mathrm{CO}_{2}$ content. For example, the glassy margin of a basaltic pillow lava will have a smaller $\mathrm{CO} / \mathrm{CO}_{2}$ ratio than its more crystalline interior. The gaseous phases most sensitive to bulk rock compositional variation are the $\mathrm{CO}_{2}, \mathrm{CO}$ and $\mathrm{SO}_{2}$ contents. Thus the olivine cumulates represented by the picritic basalts are the most enriched in the $\mathrm{CO} / \mathrm{CO}_{2}$ ratio while the most fractionated rocks such as those enriched in clinopyroxene (the plagioclase-pyroxene basalt) with or without olivine are the most depleted in $\mathrm{CO} / \mathrm{CO}_{2}$ ratios. These later are also among the rocks the most rich in $\mathrm{SO}_{2}$ content (100-175 ppm). Inter- mediate values of $\mathrm{CO} / \mathrm{CO}_{2}$ ratios and of $\mathrm{SO}_{2}$ content are found among the plagioclase-rich basalts and the olivine basalts. The lowest values of $\mathrm{SO}_{2}$ content $(<100 \mathrm{ppm})$ occur in the olivine-rich basalts located near the axis of the inner floor.

Major differences between subaqueous and subaerial volcanism are mainly confined to the $\mathrm{SO}_{2}$ and $\mathrm{HCl}$ content. In general, the subaqueous volcanics have a higher $\mathrm{HCl}$ and a lower $\mathrm{SO}_{2}$ content than does subaerial lava from the Afar region.

In the Rift Valley's inner floor, the centrally located hills are considered to represent the most recent volcanic piles exposed during the last few ten thousand years. From the present study it is inferred that the total volume of gas retained in the exposed lava of the inner floor is on the order of about 2 milliliters per centimeter cube of basaltic rocks. It is likely that with time, during ocean floor weathering and rock disintegration by tectonic activity, some of the gas included in the minerals and in the matrix of the rocks will be liberated into sea water and sediment. 


\section{REFERENCES}

ArCyanA, 1977, Rocks Collected by Bathyscaphe and Diving Saucer in the FAMOUS Area of the Mid-Atlantic Rift Valley: Petrological Diversity and Structural Setting. Deep-Sea Res., 24, p. 565-589.

Bideau D., Hékinian R. and Francheteau J. 1976, Orientation of Ocean Floor Basaltic Rocks at Time of Cooling: a General Method. Contrib. Mineral. Petrol., 65, p. 1928.

ChaIGNEAU M., 1975, Essai sur la composition des gaz magmatiques profonds. Bull. Volcanol., 34 (3), p. 1-13.

- and BoRDET, 1962, Sur le teneurs en gaz occlus et eau des rétinites et obsidiennes. Comptes-R. Acad. Sci., 225, p. 30193021.

Czamanske G.K. and Moore J.G., 1977, Composition and Phase Chemistry of Sulfide Globules in Basalt from the Mid-Atlantic Ridge Rift Valley near $37^{\circ} N$ lat. Geol. Soc. Am. Bull., 88 (4), p. 587-599.

HEALD E, F., NAUGhton J.J. and BaRnes I.L. Jr., 1963, The Chemistry of Volcanic Gases. 2. Use of Equilibrium Calculations in the Interpretation of Volcanic Gas Samples. Jour. Geophys. Res., 68 (2), p. 545-557.

HÉkinian R., Chaigneau $M$. and J. L. ChEMINÉE, 1973, Popping Rocks and Lava Tubes from the Mid-Atlantic Rift Valley at $36^{\circ} \mathrm{N}$. Nature, 245 (5425), p. 371-373.

Huntingdon A.T., 1973, The Collection and Analysis of Volcanic Gas from Mount Etna. Phil. Trans. R. Soc. Lond. A, 274, p. 119-128.

INGERSON E., 1947, Liquid Inclusions in Geologic Thermometry, Am. Mineralogist, $32(7-8)$, p. 375-388.

Iwasaki, I., T. Osawa, M. Yoshida, T. KatSURA, B. IWASAKI, $M$. Kamada and $\mathbf{M}$. Hirayama, 1962, Volcanic Gases in Japan. Tokyo Inst. Technology, Bull. n. 47, p. 1-54.

JAGGAR T. A., 1940, Magmatic Gases. Am. Jour. Sci, 238 (5), p. 313-353.

JEHL, V., 1975, Le métamorphisme et les fluides associés des roches océaniques de l'Atlantique Nord. Thèse, C.R.P.G.E.N.S.G., Université de Nancy I.

LeRoY J. and B. POTY, 1969, Recherches préliminaires sur les fluides associés à la genèse des minéralisations en uranium $d u$
Limousin (France). Mineral. Deposita, 4, p. $395-400$.

Matsuo S., 1960, On the Origin of Volcanic Gases. Jour, Earth Sciences, 8, p. 22-245.

Moore G. J. and P. FABнi, 1971, An Estimate of the Juvenile Sulfur Content of Basalt. Contr. Mineral. Petrol., 33, p. 118-127.

, J. N. Batchelder and C. G. CuN NINGHAM, 1977, CO ${ }_{2}$ filled Vesicles in MidOcean Basalt. Jour Volcanology, 2, p. 309327.

- and L. CALK, 1971, Sulfide Spherules in Vesicles of Bredged Pillow Basalt. Amer. Mineralogist, 56, p. 476-488.

- and J.G. Schilling, 1973, Vesicles, Water, and Sulfur in Reykjanes Ridge Basalts. Contr. Mineral. Petrol. , 41, p. $105-118$.

Pineau F., M. Javoy, Y. Bottinga, 1976, ${ }^{13} \mathrm{C} /{ }^{12} \mathrm{C}$ Ratios of Rocks and Inclusions in Popping Rocks of the Mid-Atlantic Ridge and Their bearing on the Problem of Isotopic Composition of Deep-seated Carbon. Earth Plan. Sci. Lett. p. 413-421.

Renard V., B. SchrumpF, J. C. Sibuet and D. CARRÉ, 1975, Bathymétrie détaillée d'une partie de la vallée du Rift et de la faille transformante près de $36^{\circ} 50^{\prime} N$ dans l'Océan Atlantique. CNEXO, Paris.

SAto M. and J. G. Moore, 1973, Oxygen and Sulfur Fugacities of Magmatic Gases Directly Measured in Active Vents of Mount Etna, Phil. Trans. R. Soc. Lond., A., 274, p. 137-146.

ROEDDER, E., 1965, Liquid $\mathrm{CO}_{2}$ Inclusions in Olivine-bearing Nodules and Phenocrysts from Basalts. Am. Mineralogist, 50, p. 17461782.

Weisbrod A., B. Poty, J. Touret, 1976, Les inclusions fluides en géochimie-pétrologie: tendances actuelles. Bull. Soc. Fr. Min. Crist., 9, p. 140-152.

White D. E. and G. A. WARING, 1963, Data of Geochemistry. Volcanic emanations. U.S. Geol. Surv. Prof. Paper, 440 K.

Ms made available to the IAVCEI Publication Office for the press Nov. 1978. 